\title{
Monitoring European forests: results for science, policy, and society
}

\author{
Pasi Rautio $^{1} \cdot$ Marco Ferretti $^{2}$
}

Received: 29 June 2015 / Accepted: 16 July 2015 / Published online: 25 August 2015

(C) INRA and Springer-Verlag France 2015

Forest inventories have been carried out in Europe for centuries with the view to secure the wood supply. The first forest surveys based on probabilistic sampling design started in the early 1920 s with the aim to provide information about sustainability of wood use at national level. The origin of forest monitoring is much more recent as it often rises from international information needs that demand answers from coordinated multidisciplinary research. In Europe forest monitoring started in the 1970s to respond to urgent scientific, political, and societal questions related to the alleged forest decline in relation to air pollution. At that time, the concern on possible effects of air pollutants was at the top of the political agenda and led to an unprecedented, international effort, like the United Nations Convention on Long-range Transboundary Air Pollution (CLRTAP, Geneva 1979) signed by 51 parties. Within the CLRTAP, International Co-operative Programme

Handling Editor: Erwin Dreyer and Marianne Pfeiffer

Contribution of the co-authors P. Rautio: Guest editor of the "ICP Forests 2014" special issue, writing of the manuscript.

M. Ferretti: guest editor of the "ICP Forests 2014" special issue, writing of the manuscript.

Key message: The special issue reports on results presented in the ICP Forests Scientific Conference 2013 "Today's evaluations and future monitoring" held in Belgrad, where several issues related to the biological response of forests to environmental factors, as well as new tools, ideas and concept were addressed.

\section{Pasi Rautio}

pasi.rautio@luke.fi

Marco Ferretti

ferretti@terradata.it

1 Natural Resources Institute Finland (Luke), Eteläranta 55, FI-96301 Rovaniemi, Finland

2 TerraData Environmetrics, Via L. Bardelloni 19, I-58025 Monterotondo M.mo, GR, Italy on the Assessment and Monitoring of Air Pollution Effects on Forests (ICP Forests) was installed and launched in 1985.

Much work, with great enthusiasm and with improved quality, has been done over the past 30 years. At the same time, however, it is easy to realize that-while the demand for the monitoring of European forest boosted the set-up of internationally coordinated forest monitoring initiatives - the support has considerably slowed down over time. There are many reasons behind this loss of support (e.g., Skelly and Innes 1994; Peterman 1990; Legg and Nagy 2006; Lindenmayer and Likens 2009), but now reconciling monitoring with science, policy, and society has been repeatedly claimed to be an important target (e.g., Ferretti and Fischer 2013). This target may be achieved by making forest monitoring (i) of high quality (e.g., Sulkava et al. 2007) and compliant with key scientific requirements, (ii) capable to address forest and environmental issues that are of concern for our society, and (iii) able to provide answers to political questions (Ferretti 2011). This is particularly true for a programme like ICP Forests, which has a clear mandate rooted in the UNECE CLRTAP.

The 2nd ICP Forests Scientific Conference "Today's evaluations and future monitoring" held in Belgrad, Serbia in 2013, intended to launch a signal in this direction. It was a one-day event attended by 70 scientists and experts from 21 countries, with an impressive number of oral presentations (21) and posters (28). Several issues related to the biological response of forests to environmental factors, the factors driving the biological response, as well as new tools, ideas, and concepts were addressed (Ferretti and Fischer 2013). Particular emphasis was placed on atmospheric deposition, its impact on tree and soil compartments and on reliable measurement methods.

Selected papers arising from the conference are published in this special issue of Annals of Forest Science, "ICP Forests 
2014 - Monitoring European Forests: results for science, policy and society". The papers cover several aspects, including

- the multi-purpose use of inventory and monitoring network: from the investigation on patterns related to pine sawfly and Scleroderris canker (Nevalainen et al. 2015), to the estimation of ozone risk for forests and human health (Cristofori et al. 2015), and to a platform for large-scale mycorrhizal studies (Suz et al. 2015);

- the role of nitrogen deposition on soil chemistry, tree nutrition and tree defoliation (Ferretti et al. 2015; Waldner et al. 2015; Talkner et al. 2015)

Acknowledgments When introducing this special issue we would like to acknowledge the members of the Scientific Committee of the Conference (Bruno De Vos INBO, Belgium; Richard Fischer, TI, Hamburg, Germany; Karin Hansen, IVL, Sweden; Marcus Schaub, WSL, Switzerland) and the organizers of the conference (Institute of Forestry, Serbia and Programme Coordinating Centre of ICP Forests). We are grateful to all those that submitted their manuscript for this special issue. Last, but not least, sincere thanks to Erwin Dreyer and Marianne Pfeiffer (INRA Nancy) for their efforts in coordinating the editorial work of this special issue.

\section{References}

Cristofori A, Bacaro G, Confalonieri M, Cristofolini F, Frati L, Geri F, Gottardini E, Tonidandel G, Zottele F, Ferretti M (2015) Estimating ozone risks using forest monitoring networks - results for science, policy and society. Ann For Sci. doi:10.1007/s13595-014-0440-y

Ferretti M (2011) Quality assurance: a vital need in ecological monitoring. CAB Rev Perspect Agric Vet Res Nutr Nat Resour 6:1-14

Ferretti M, Fischer R (2013) Forest monitoring. Dev Environ Sci 12:483496

Ferretti M, Calderisi M, Marchetto A, Waldner P, Thimonier A, Jonard M, Cools N, Rautio P, Clarke N, Hansen K, Merilä P, Potočić N (2015)
Variables related to nitrogen deposition improve defoliation models for European forests. Ann For Sci. doi:10.1007/s13595-014-0445-6

Legg CJ, Nagy L (2006) Why most conservation monitoring is, but need not be, a waste of time. J Environ Manag 78:194-199

Lindenmayer DB, Likens GE (2009) Adaptive monitoring: a new paradigm for long-term research and monitoring. Trends Ecol Evol 24: 482-486

Nevalainen S, Sirkiä S, Peltoniemi M, Neuvonen S (2015) Vulnerability to pine sawfly damage decreases with site fertility but the opposite is true with scleroderris canker damage; results from Finnish ICP forests and NFI data. Ann For Sci. doi:10.1007/s13595-014-0435-8

Peterman RM (1990) The importance of reporting statistical power: the forest decline and acidic deposition example. Ecology 71:20242027

Skelly JM, Innes JL (1994) Waldsterben in the forests of central Europe and eastern North America: fantasy or reality? Plant Dis 78:10211032

Sulkava M, Luyssaert S, Rautio P, Janssens IA, Hollmén J (2007) Modeling the effects of varying data quality on trend detection in environmental monitoring. Ecol Inform 2:167-176

Suz L, Barsoum N, Benham S, Cheffings C, Cox F, Hackett L, Jones A, Mueller G, Orme D, Seidling W, Van Der Linde S, Bidartondo M (2015) Monitoring ectomycorrhizal fungi at large scales for science, forest management, fungal conservation and environmental policy. Ann For Sci. doi:10.1007/s13595-014-0447-4

Talkner U, Meiwes K, Potočić N, Seletković I, Cools N, De Vos B, Rautio P (2015) Phosphorus nutrition of beech (Fagus sylvatica L.) is decreasing in Europe. Ann For Sci. doi:10. 1007/s13595-015-0459-8

Waldner P, Thimonier A, Graf Pannatier E, Etzold S, Schmitt M, Marchetto A, Rautio P, Derome K, Nieminen T, Nevalainen S, Lindroos AJ, Merilä P, Kindermann G, Neumann M, Cools N, de Vos B, Roskams P, Verstraeten A, Hansen K, Pihl Karlsson G, Dietrich HP, Raspe S, Fischer R, Lorenz M, Iost S, Granke O, Sanders T, Michel A, Nagel HD, Scheuschner T, Simončič P, von Wilpert K, Meesenburg H, Fleck S, Benham S, Vanguelova E, Clarke N, Ingerslev M, Vesterdal L, Gundersen P, Stupak I, Jonard M, Potočić N, Minaya M (2015) Exceedance of critical loads and of critical limits impacts tree nutrition across Europe. Ann For Sci. doi: 10.1007/s13595-015-0489-2 